\title{
SELENIUM AS AN INDICATOR ELEMENT IN GEOCHEMICAL EXPLORATION
}

\author{
TAPIO KOLJONEN
}

\begin{abstract}
KOLJONEN, TAPIO 1977: Selenium as an indicator element in geochemical exploration. Bull. Geol. Soc. Finland, 49 (2): 85-88.

Selenium is always present in sulphide ores and can be used as an indicator element in the geochemical exploration of those ores. Being an anion selenium also gives information, e.g., about ore type, that cannot be obtained through the analysis of cations alone. When sulphides weather in acid soils selenium is oxidized to elemental form or to selenite, it is adsorbed onto colloids, and migrates with difficulty. Therefore, high selenium contents occur in colloid-rich sediments in restricted areas near sulphide mineralizations. The mineralizations can be located by analysing such sediments as gossan, till, lake and river sediment, and organic- and iron-rich layers in podzolic soil. Selenium content is increased also in vegetation growing on selenium-rich soils but the increase observed has been small. When the $\mathrm{pH}$ of sediments is neutral or nearly neutral, e.g., in calcareous areas, selenium is oxidized to selenate, which form easily dissolves, and the anomaly near sulphide mineralizations is not as distinct as in acid soils.

Tapio Koljonen, Department of Geology and Mineralogy, University of Helsinki, P.O. Box 115, SF-00171 Helsinki 17, Finland. (Address until 2. 11. 1979: University of Dar es Salaam, Department of Geology, P.O. Box 35602, Dar es Salaam, Tanzania.)
\end{abstract}

\section{Introduction}

Selenium replaces sulphur diadochially and hence is always present in sulphide ores and a common by-product when such ores are mined. Their geochemistries coincide in many respects since the ionic radii of $\mathrm{Se}$ and $\mathrm{S}$ are similar. In magmatic processes $\mathrm{Se}$ is more strongly enriched than $\mathrm{S}$ into late differentiates, together with elements such as As, Sb, $\mathrm{Hg}$, and $\mathrm{Ag}$, and is commonly found in high temperature volcanic emanations. Se partly separates from $\mathrm{S}$ is sedimentary processes where it is oxidized to elemental form or to selenite, while $\mathrm{S}$ is oxidized predominantly to sulphate.

Geochemical exploration is usually based on the anomalous contents of cations. Se is one of the few anions that can be widely used. Its use as an indicator element has been increasing of late with the development of instrumental analytical methods (e.g. Crenschaw and Lakin 1974, Schnepfe 1974, Terada et al. 1975). When the concentration of Se in sulphide ores and nearby soils is 0.5 ppm or higher, it can be measured easily.

The present report is based on earlier studies related to the general geochemistry 
Table 1. Selenium content in some uranium ores, iron-rich oxidate sediments, and iron ores, mostly from Finland.

\begin{tabular}{|c|c|c|c|}
\hline No. & Sample & Locality & Se ppm \\
\hline 1 & $\begin{array}{l}\text { Uranium mineralization (pitchblende) in quartzite. } \\
\text { U } 3.8^{\%} \%\end{array}$ & Eno, Paukkajanvaara & 0.35 \\
\hline 2 & $\begin{array}{l}\text { Uranium mineralization (pitchblende) in metadia- } \\
\text { base. U } 3.1 \%\end{array}$ & Eno, Paukkajanvaara & 0.41 \\
\hline 3 & Quartzite & Eno, Paukkajanvaara & 0.15 \\
\hline 4 & Carbonaceous shale, uranium ore. U $0.03 \%$ & Sweden, Billingen & 1.12 \\
\hline 5 & Cossan, containing jarosite & Eno, Otravaara & 21.0 \\
\hline 6 & Gossan, containing jarosite & Eno, Otravaara & 9.5 \\
\hline 7 & Gossan, containing jarosite & Eno, Otravaara & 5.3 \\
\hline 8 & Gossan, containing jarosite & Eno, Otravaara & 4.5 \\
\hline 9 & Gossan, containing jarosite & Eno, Otravaara & 4.3 \\
\hline 10 & Gossan & Eno, Otravaara & 1.7 \\
\hline 11 & Sand, cemented with Fe-hydroxides & Eno, Otravaara & 1.7 \\
\hline 12 & Gossan & Eno, Otravaara & 0.4 \\
\hline 13 & Iron ore, sedimentary & USSR, Krivoi Rog & 0.3 \\
\hline 14 & Oolitic iron ore & BRD, Harzburg & 0.2 \\
\hline 15 & Mn-rich iron ore, sedimentary & Ylistaro, Vittinki & 0.2 \\
\hline 16 & Hematite ore, magmatic & Kemijärvi, Raajärvi & 0.1 \\
\hline
\end{tabular}

of selenium. The detailed results have been published elsewhere (Koljonen 1973a, b, c; $1974 \mathrm{a}, \mathrm{b}, \mathrm{c} ; 1975 \mathrm{a}, \mathrm{b})$. In this paper the properties of Se that have proven useful in geochemical exploration are reported, together with a few new analyses.

\section{Sulphide ores}

The most important sulphide ores in Finland appear to be hydrothermal or exhalative-sedimentary in origin (cf., Kahma 1973). Selenium is enriched into volcanic emanations and Se content is high, about $1-50 \mathrm{ppm}$ in the economically most important sulphide ores. High Se content in sulphides can thus be taken as an indicator of hydrothermal origin or sedimentation from volcanic emanations. Through measurement of Se the ore type may be recognized even such indicator elements as $\mathrm{Cu}, \mathrm{Co}, \mathrm{W}$, and $\mathrm{Zn}$ are absent.

The average content of selenium in the Earth's crust is $0.05 \mathrm{ppm}$. The content is increased in the rocks around ore bodies and even in the igneous rocks cutting the ore. The increase in igneous rocks is not easily detected, however, because of the analytical difficulties encountered.

In sedimentary sulphides the $\mathrm{S} / \mathrm{Se}$ ratio is $30000-50000$ in magnitude and in Outokumpu-type ores and in carbonaceous schists 2 000-10 000 (Koljonen 1975b). The Se content in carbonaceous schists, like that in sulphide ores, is about $10 \mathrm{ppm}$. The content is high because Se, as a nutrient, is collected by organisms and also enriched with organic detritus during sedimentation.

\section{Uranium ores}

Selenium and uranium are precipitated by organisms and organic colloids and are often found together in sedimentary rocks, e.g., in Paleozoic slates in Sweden (Table 1, No. 4).

Se seems to be enriched with $U$ in both sedimentary and magmatic ores. Häkli, Vuorelainen, and Sahama (1965) found new selenides in albite diabases containing $U$, and Se is also enriched in the small $U$ ores found in quartzites in Eno, S.E. Finland (Table 1, Nos. 1-3).

$\mathrm{U}$ exploration is mostly carried out by ana- 
lyzing for $\mathrm{U}$ or measuring the radiation. However, increased Se content in rocks, e.g., in carbonaceous schists and sediments, indicates areas favorable for prospecting.

\section{Gossans}

Se is enriched into oxidate sediments and forms insoluble iron-selenites. It is therefore present in the weathering products of sulphide ores even when most cations and $\mathrm{S}$ have been leached out (Table 1, Nos. 5-12). Through the analysis of Se in rusty weathering products gossans can be identified and easily distinguished from common oxidate sediments (cf., e.g., Koljonen et al. 1976) and iron ores (Table 1, Nos. 13-16). Se concentration is usually higher in sedimentary than in magmatic iron ores, because in exogenic processes Se in enriched to iron hydroxides and in endogenic processes to sulphides.

\section{Sediments}

Aroud sulphide ores, Se content is increased in all sediments containing colloids. In acid soils, such as podzols, Se behaves as a resistate, and the content is increased in till, clay, organic-rich lake sediments - gyttjas and dys - and in podzols in top soil and the iron-rich B-horizon.

\section{Vegetation}

In Se-rich areas, especially in the USA, plant species that accumulate Se have been used as indicator plants in uranium exploration.
Se generally migrates with difficulty in Finnish soils and thus far no plant has been found to be an accumulator. The concentration in dried plants growing near or upon sulphide-rich rocks is about $10 \%$ of that found in soil. The content near sulphide mineralizations is increased but the increase is small.

In Ca-rich soils the mobility of Se increases because of its oxidation and greater solubility. Se is more available to plant consumption than in podzolic soils and the contens is increased in vegetation. Substantiating this are the Se poisonings observed in cattle that have consumed seleniferous plants in calcareous areas; e.g., in Ireland (Walsh et al. 1951).

\section{Dissussion}

In acid soils Se is oxidized to elemental form $\left(\mathrm{Se}^{2-} \rightarrow \mathrm{Se}^{0}\right)$ and, behaving as a resistate, is adsorbed on colloids. In weathering rock containing bases (e.g., skarn rocks) Se is oxidized to selenite $\left(\mathrm{Se}^{0} \rightarrow \mathrm{SeO}_{3}{ }^{2-}\right)$ more readily than in podzolic soils (Koljonen 1975a). If considerable iron is present as in sulphide ores, selenite is bound to the weathering products and does not migrate even when most cations and sulphur are depleted in soils. Because of the low mobility of Se in most Finnish soils, anomalously high contents are found in restricted areas near sulphide mineralizations. For exploration purposes Se may analysed advantageously in such colloid-rich sediments as iron hydroxides, organic rich soils, and tills. Selenium anomalies in vegetation near sulphide mineralization seem to be weak.

An indication of ore type may be achieved by determining the $\mathrm{S} / \mathrm{Se}$ ratio. 


\section{References}

Crenshaw, G. L. and Lakin, H. W. (1974) A sensitive and rapid method for the determination of trace amounts of selenium in geologic materials. J. Res. U.S. Geol. Surv. 2: 483-487.

Häkli, T. A., Vuorelainen, J., and Sahama, Th. G. (1965) Kitkaite (NiTeSe), a new mineral from Kuusamo, northeast Finland. Am. Min. 50: 581-586.

Kahma, A. (1973) The main metallogenic features of Finland. Geol. Surv. Finland, Bull. 265.

Koljonen, T. (1973a) Selenium in certain igneous rocks. Bull. Geol. Soc. Finland 45: 9-22.

- (1973b) Selenium in certain metamorphic rocks. Bull. Geol. Soc. Finland 45: 107-117.

- (1973c) Selenium in certain sedimentary rocks. Bull. Geol. Soc. Finland 45: 119-123.

- (1974a) Selenium in certain Finnish sediments. Bull. Geol. Soc. Finland 46: 15-21.

- (1974b) Behavior of selenium in silicic vein rocks and near granitic contacts. Bull. Geol. Soc. Finland 46: 133-138.

- (1974c) Selenium uptake by plants in Finland. Oikos 25: 353-355.
- (1975a) The behavior of selenium in Finnish soils. Ann. Agric. Fenn. 14: 240-247.

- (1975b) Behavior of selenium and sulfur in Svecokarelian sulfide-rich rocks. Bull. Geol. Soc. Finland 47: 25-31.

-, Lahermo, P., and Carlson, L. (1976) Origin, mineralogy, and chemistry of manganiferous and ferruginous precipitates found in sand and gravel deposits in Finland. Bull. Geol. Soc. Finland 48: 111-135.

Schnepfe, M. M. (1974) Spectrofluorimetric procedure using 2,3-naphthalenediamine for determining selenium in rocks. J. Res. U.S. Geol. Surv. 2: $631-636$.

Terada, K., Ooba, T., and Kiba, T. (1975) Separation and determination of selenium in rocks, marine sediments and plankton by direct evolution with the bromide-condensed phosphoric acid reagent. Talanta 22: 41-49.

Walsh, T., Fleming, G. A., O'Connor, R., and Sweeney, A. (1951) Selenium toxicity associated mith an Irish soil series. Nature 168: 881.

Manuscript received April 24, 1977. 